\title{
Pluralism at the Twilight of Franco's Spain: Antifascist and Intersectional Practice
}

\author{
Louie Dean Valencia-García \\ Department of History, Assistant Professor of Digital History, Texas State \\ University, San Marcos, Texas, USA \\ Senior Fellow, Centre for the Analysis of the Radical Right \\ LValencia@txstate.edu
}

\begin{abstract}
Since the late 1980s, the term 'intersectionality' has been used as a way to describe ways in which socially constructed categories must be considered in conjunction to better understand everyday oppression. This article presents a broad understanding of pluralism as antifascist practice, whilst studying antifascist publications in Spain during the 1970s, considering intersectional analysis and methodology. Many of the producers of these publications saw themselves as explicitly antifascist or at the very least part of a countercultural movement which challenged social norms promoted under the late fascist regime. By looking at these antifascist movements, using intersectional approaches, we can better understand how fascism itself functions and how it can be disentangled - as scholarship on fascism has largely ignored how intersectional analytical approaches might give us new insights into fascism.
\end{abstract}

\section{Keywords}

Spain - fascism - antifascism - 1970s - youth - women - intersectionality - critical theory

The history of twentieth century Spain is one that includes both tragic loss to fascist ideologies and an intermittent but steady struggle and victory against fascism - embodied most famously in the Spanish Civil War (1936-39) and the later transition to democracy (1975-82). Socialists, liberals, anarchists and communists of many varieties all tried to resist the far right during the war and in the

(C) LOUIE DEAN VALENCIA-GARCÍA, 2020| DOI:10.1163/22116257-09010001

This is an open access article distributed under the terms of the prevailing CC-BY-NC license at the time of publication. 
years after. National Catholicism, the ideological programme of Spanish dictator Francisco Franco, was a commixture of militarism, nationalism, patriarchy, religion and Spain's own strain of fascism, Falangism. ${ }^{1}$ Under Franco, Spain's fascism resulted in the enslavement, incarceration, murder and exile of people who did not conform to strict social norms (including feminists, anarchists, communists, socialists and members of the LGBT community). ${ }^{2}$ The new dictatorship enforced those norms through legal and military measures that harshly suppressed opposition-contributing to what historian Paul Preston has described as a 'Spanish Holocaust'. ${ }^{3}$ The clearest articulation of Spain's fascist programme was the work of Pilar Primo the Rivera, an aristocrat and the sister of the fallen founder of Spain's fascist party, José Antonio Primo de Rivera. Pilar Primo de Rivera led the Sección Feminina de la Falange [Female Section of the Falange] from 1934 until 1977-outlasting both Franco and her brother. ${ }^{4}$ Her governmental organisation took a leading role in the education of all girls and

1 This antisemitism was particularly evident in the regime's celebration of a particular image of a bygone Spain that had persecuted queer people, oppressed women, excised Jews and Muslims, and conquered much of the Americas in the name of Christianity.

2 For more elaborated studies of specific ways in which the Franco regime oppressed minority groups, see: Geoffroy Huard, Los antisociales: Historia de la homosexualidad en Barcelona y París, 1945-1975 (Madrid: Marcial Pons Historia, 2014); Gema Pérez-Sánchez, Queer Transitions in Contemporary Spanish Culture: From Franco to La Movida (Albany: State Univeristy of New York Press, 2007); Raymond Carr and Juan Pablo Fusi Aizpurúa, Spain, Dictatorship to Democracy (London: Allen \& Unwin, 1981); Brice Chamouleau, Tiran al maricón: Los fantasmas 'queer' de la democracia (1970-1988): Una interpretación de las subjetividades gais ante el estado español (Madrid: Akal, 2017); Javier Ugarte Pérez, ed., Una discriminación universal: La homosexualidad bajo el franquismo y la transición, Colección G (Barcelona: Egales Editorial, 2008); Jaume Fabre, Josep Maria Huertas, and Antoni Ribas, Vint anys de resistència catalana (1939-1959) (Barcelona: La Magrana, 1978); Kerman Calvo, ¿Revolución o reforma? La transformación de la identidad política del movimiento LGTB en España, 1970-2005 (Madrid: Consejo Superior de Investigaciones Científicas, 2017).

3 See Paul Preston, The Spanish Holocaust: Inquisition and Extermination in Twentieth-Century Spain (New York: W.W. Norton and Company, 2012). For a broad outline of fascist tendencies and to see how those tendencies continued in Franco's Spain well into the 197os, see Louie Dean Valencia-García, Antiauthoritarian Youth Culture in Francoist Spain: Clashing with Fascism (London: Bloomsbury Academic, 2018), 32-56.

4 During the transition to the Spanish democracy, Franco's party, the Falange de las J.O.N.S., reorganised itself and continues operating today, with minority support. For more on the Sección Feminina, and women in Franco's Spain more generally see: Inbal Ofer, Señoritas in Blue: The Making of a Female Political Elite in Franco's Spain (Brighton, England: Academic Press, 2010); Aurora G. Morcillo, The Seduction of Modern Spain: The Female Body and the Francoist Body Politic (Lewisburg: Bucknell University Press, 2010); Aurora G. Morcillo, True Catholic Womanhood: Gender Ideology in Franco's Spain (DeKalb: Northern Illinois University Press, 2008); Kathleen Richmond, Women and Spanish Fascism: The Women's Section of the Falange, 1934-1959 (London: Routledge, 2003). 
boys who grew up under the dictatorship - which included a systematic disparagement of leftism and the inculcation of nationalist, patriarchal and religious values. ${ }^{5}$ In total, Franco's Spain had more years of fascism during the twentieth century than any other European country - a dramatic inversion of the century before, when Spain was largely an example of European liberalism. ${ }^{6}$

Scholars such as Juan Linz have argued Franco's National Catholic regime was not fascist, but rather authoritarian with limited pluralism. ${ }^{7}$ However, Franco's Spain consistently maintained fascistic tendencies in its law, education system, bureaucratic structure and was popularly understood as fascist-especially by those who stood against it. ${ }^{8}$ As many historians have demonstrated, Catalans, Basques, queer people, religious minorities, liberals and leftists all suffered oppression under Franco, including prison and forced labour camps. ${ }^{9}$ Although many of these same groups suffered in liberal democracies, this does not negate the fascistic nature of the Franco regime, but rather underlines the existence of such fascistic tendencies even within liberal democracies-the ideological inheritance of patriarchy, xenophobia, classism, nationalism and colonialism. If pluralism is indeed antithetical to fascism, which seeks categorical purity, as I contend, then, in reality, this 'authoritarianism' with limited pluralism' of which Linz spoke was always a poorly disguised euphemism for late fascism..$^{10}$ Given the fascistic nature of the Franco regime, in order to be successful, Spain's transition to democracy inherently had to be antifascist.

Whilst the antifascism of the later dictatorship and transition to democracy often involved direct actions-community organisation, protests, boycotts, strikes, etc., ${ }^{11}$ it also necessitated education and promoting consciousness

5 Valencia-García, Antiauthoritarian Youth Culture in Francoist Spain, 32-56.

6 Historian Adrian Shubert notes that between the 1812 and 1914 Spain had more years of representative, constitutional government than any other country in continental Europeincluding France, taking into consideration the twenty years of the Second French Empire. See: Adrian Shubert, A Social History of Modern Spain (London: Routledge, 1996), 5, 265.

7 See Juan J. Linz, Totalitarian and Authoritarian Regimes (Boulder, Colorado: Lynne Rienner Publishers, 2000).

8 See chapter two of Valencia-García, Antiauthoritarian Youth Culture in Francoist Spain.

9 Franco's young regime even offered a list of 6,ooo Jews to send to Hitler's camps. Jorge M. Reverte, 'La lista de Franco para el Holocausto,' El País (Madrid), June 20, 2010, Domingo ed., Reportaje sec.

10 I conceive of fascism as not being a static ideology of the past, but rather, something variegated and evolving. As scholars can imagine different iterations of feminism as 'waves' or capitalism (proto, industrial, late), I conceive of fascism as not being strictly limited to Mussolini's Italy. To this end, I consider Franco's National-Catholicism as ideologically inheriting from José Antonio's Falange vis-à-vis Pilar Primo de Rivera.

11 See Pamela Beth Radcliff, Making Democratic Citizens in Spain: Civil Society and the Popular Origins of the Transition, 1960-78 (New York: Palgrave Macmillan, 2011). 
of how oppressions operate. In order to better comprehend how antifascist thought and practice evolved after the Second World War, it is helpful to understand both the construction of 'intersectionality' and what is today known as 'critical theory' - a philosophy built to understand and combat fascism. Jeremiah Morelock notes, 'One of the most famous messages from the Institute for Social Research is that liberal-democratic societies tend to move toward fascism.'. ${ }^{2}$ Initially, much of the early work of the Institute for Social Research — the Frankfurt School—focused on questions surrounding capitalism; however, the experience of Nazism broadened their work to also consider what caused fascism-which necessitated a different set of tools to understand why certain groups were targeted by fascism and why fascism finds its origins within liberal democracies. The 'New Left' and the legacy of the Frankfurt School was exemplified by the work of Herbert Marcuse, the May '68 protests, and the work of activist scholars, including Angela Davis, Kimberlé Williams Crenshaw and Judith Butler. Emerging from the tradition of critical theory, the concept of 'intersectionality' has been used to describe ways in which socially constructed categories must be considered in conjunction to better understand everyday oppression (what I consider the kindling for fascism) ${ }^{13}$ Critical theory acknowledges that fascism cannot be understood solely through a singular mode of analysis, but rather, must always consider the interwoven ways in which fascistic oppressions work. Understanding this everyday oppression helps us to understand fascism and gives us a vocabulary to dissect and disassemble it. From an intersectional analytical perspective, fascism is an extreme form of anti-pluralism that often targets people through ableism, anti-liberalism, classism, ethnocentrism, nationalism, patriarchy, homophobia, racism and xenophobia. Whilst each manifestation of fascism uses different amounts of each variable, together these oppressions are constituent of fascism. Considering this formula, antifascism can be defined by efforts to combat these oppressions either in one's everyday life or as part of a more explicit political programme. Of course, this does not negate other

12 Jeremiah Morelock, Critical Theory and Authoritarian Populism (London: University of Westminster Press, 2018), xiii.

13 Intersectionality has been a useful frame work of analysis since at least the publication of Kimberlé Williams Crenshaw's 'Demarginalizing the Intersection of Race and Sex: A Black Feminist Critique of Antidiscrimination Doctrine, Feminist Theory and Antiracist Politics,' University of Chicago Legal Forum 1989, no. 1. The work asked scholars to consider race and gender together to better understand the experiences of black women. Since then, intersectionality has grown to describe the ways in which all marginalised and oppressed people encounter intersecting oppressions based on their race, gender, sexuality, class, nationality, ethnicity and embodiment. 
well-known symptoms of fascism that describe the aesthetics and implementation of fascism, such as authoritarianism, a cult of personality, forced labour, ideological contradictions, militarism, palingenetic tendencies, populism, ritualism, surveillance, violence, etc.

Whilst the term 'intersectionality' can be a slippery heuristic, I use it to describe how 'categories of historical analysis' - such as class, embodiment, ethnicity, gender, nation, race, religion and sexuality—are inextricably linked. ${ }^{14}$ This article will present a broader understanding of pluralism and intersectional methods as part of antifascist practice through a survey of left-leaning publications - pamphlets, books, magazines and zines-from the twilight of Franco's Spain. This article does not present a comprehensive chronological overview of the many Spanish antifascist groups active in the period, but rather demonstrates ways in which pluralist practices were reflected in a variety of Spanish antifascist publications of the 1970s. The producers of these publications saw themselves as explicitly antifascist or, at the very least, part of a countercultural movement that challenged Francoist social norms. By looking at these antifascist publications and using intersectional approaches, we can better understand how fascism functions and how it can be disentangled. Through this study of these publications from Spanish antifascist movements of the 1970 s we can better comprehend how antifascist action required intersectional approaches so that to combat Francoism, thus giving us a deeper understanding of fascism itself.

\section{Spanish Fascism and Antifascism Through Critical Theory and Intersectional Methods}

Antifascism was never about simply being against a vague idea of fascism, but has been a struggle to unravel fascism-requiring knowledge of how fascism works. In the postwar years, scholars of the Frankfurt School developed critical theory to understand what brought people to fascism-leading to the creation of what came to be known as intersectional methodology. To this end, I consider intersectional thinking and analysis to be antifascist. However, for reasons that are unclear, many scholars studying fascism have resisted explicitly incorporating intersectional methods into their study of fascism-which would necessarily challenge and complicate our understanding of how fascism works as elaborated upon by scholars such as Payne, Griffin and Paxton, and

14 For more on 'categories of historical analysis' see Joan W. Scott, 'Gender: A Useful Category of Historical Analysis,' The American Historical Review 91, no. 5 (1986): 1053-1075. 
many of their successors. ${ }^{15}$ I understand 'intersectionality' not as a goal for which to strive, but instead see it as a methodology and praxis used to understand the ways in which hegemonic systems of power use and invent social categories (class, gender, nation, race, etc.) to simultaneously marginalise people from power and, often, to alienate them from each other-creating 'competing interests'. Intersectional methods give us the ability to deconstruct and understand the overlapping ways socially constructed categories interact with each other and their relationship to hegemonic power and quotidian interactions.

Most scholars of fascism clearly have put importance on issues of nationalism over other categories of historical analysis. The logic goes that nationalism propelled discrimination and that the other categories were important, but less so when placed next to nationalism. It is time to bring together the study of fascism and critical theory by more explicitly incorporating intersectionality into the study of fascism. We make the mistake of taking fascists at their word that nation is the supreme category to consider. It is impossible to understand fascism without using intersectional methods-no form of oppression happens in isolation. As antifascist activists make clear, the study of fascism requires the use of intersectionality as a theoretical framework because fascism itself is fundamentally an intersectional phenomenon.

Under fascism, identity is utilised to define who can be considered part of a given 'imagined community' - to borrow from Benedict Anderson. Because of an imagined belief in purity, many people are left out of a community because of their perceived ethnicity, nationality or race-others because of age, disability, political ideology, reproductive potential or sexuality. In a sense, those extricated are 'queer'. Fascism marginalises non-conforming people and then melds them into a category of 'other', whilst simultaneously often pitting those groups against each other. Antifascism requires a nuanced understanding of power and the ways in which fascist ideologies promote homogeneity

15 In none of the most prominent works of fascism have scholars discussed the need to think intersectionally about fascism, see: Roger Griffin, The Nature of Fascism (London: Routledge, 1993); Stanley G. Payne, A History of Fascism, 1914-1945 (Madison: University of Wisconsin Press, 1995); Robert O. Paxton, The Anatomy of Fascism (New York: Alfred A. Knopf, 2004); Ruth Ben-Ghiat, Fascist Modernities: Italy, 1922-1945 (Berkeley, California: University of California Press, 2004); Dylan J. Riley, The Civic Foundations of Fascism in Europe: Italy, Spain, and Romania, 1870-1945 (Baltimore: Johns Hopkins University Press, 2010); Jason Stanley, How Fascism Works: The Politics of Us and Them (New York: Random House, 2018). For a more complete description of intersectional and questions related to the Anthropocene and the study of fascism, see Louie Dean Valencia-García, 'Locating Dictatorship in the Anthropocene: Historiographic Trends in the History of Science and Technology and the Study of European Authoritarianism,' Contemporary European History 28, no. 1 (2019): 120-130. 
by excising diversity. In this way, unlikely allies can come to realise that their oppressions are interconnected. Intersectional methodologies help us to understand this process and to disentangle and understand such oppression both at systemic and everyday levels.

As early feminist, anti-colonialist, abolitionist, socialist and even sexual (uranian) rights movements were beginning to find common ground in the late nineteenth and early twentieth centuries, ${ }^{16}$ a reactionary wave formed against those freedom movements, coalescing into fascist ideology-particularly amongst disaffected white men and women who saw equality as a threat to their own societal positions. Amongst a white working class already beaten under industrial capitalism, this imagined anxiety of economic and social threat posed by the ascension of previously marginalised groups pushed them to fevered populist extremes henceforth unimaginable. After the Holocaust, it became clear that it was important to name and deconstruct the hierarchical power structures that marginalised and threatened those excised from hegemonic power-whose human dignity was denied them. In the Spanish case, during the twilight of Franco's Spain, intersectional organising praxis emerged out of necessity against the regime.

Historian of Spain and antifascist activist, Mark Bray, argues antifascism 'is many things, but perhaps most fundamentally it is an argument about the historical continuity between different eras of far-right violence and the many forms of collective self-defence that it has necessitated across the globe over the past century. ${ }^{17} \mathrm{~A}$ 'collective self-defence' implies intersectional interests-promoting solidarity with those whom might seemingly be different. For Bray, antifascism also rejects the 'classical liberal' belief that one can disapprove of what one says but still defend to the death one's right to say it. Instead, he argues: 'After Auschwitz and Treblinka, antifascists committed themselves to fighting to the death the ability of organized Nazis to say anything.' ${ }^{18}$ For the antifascist, a group's identity, humanity and rights were not up for debate. In order to effectively fight fascism, interests amongst a myriad of social groups have to be recognised and be taken seriously when organising.

Because of the overlapping ways that fascist thinkers meld diverse identities into a singular category of 'other', fascist actions and ideologies require

16 For examples from the Spanish case in particular, see Christopher Schmidt-Nowara, Empire and Antislavery: Spain, Cuba, and Puerto Rico, 1833-1874 (Pittsburgh: University of Pittsburgh Press, 1999). For more on homosexual rights movements in the years before the rise of Nazi Germany, see Javier Samper Vendrell, The Seduction of Youth: Print Culture and Homosexual Rights in the Weimar Republic (Toronto: University of Toronto Press, 2020).

17 Mark Bray, Antifa: The Anti-Fascist Handbook (Brooklyn: Melville House, 2017), xix.

18 Bray, Antifa, xv. 
intersectional analysis to understand this process of othering. This is to say, it was because of fascism's own intersectional, hegemonic oppression that scholars and activists had to also think intersectionally—in order to both understand fascism and to find solidarity against an oppression that sought to divide and exterminate. Intersectional methodology is a necessary response to confront and understand fascism's interwoven and interconnected forms of oppression. As for the cure to fascism, namely antifascism, it lies not solely in the study or recognition of overlapping interests amongst marginalised groups, but also in the practise of acceptance and celebration of individuals and pluralistic communities - an instrument which lies outside of the fascist toolbox. Indeed, this is why many contemporary fascistic thinkers loath 'multiculturalism.'19 Intersectional methodologies provide an important tool to understand what powers fascism, but do not provide an antidote. For this we must remember Audre Lorde's dictum that the 'master's tools will never dismantle the master's house', which hangs quietly in the background of these discussions, warning scholars that intersectionality, as a tool, cannot dismantle the master's house alone. ${ }^{20}$ As antifascists in Spain came to realise in the 197os, that can only be done through the practice and promotion of pluralism - a tool which does not belong to fascism.

Although few Spanish antifascist groups in the 1970s looked at issues of class, embodiment, ethnicity, gender, nation, race and sexuality holistically, as interconnected and inextricable, they did find themselves organising in ways that could be described as intersectional. Coming to a consciousness of intersecting interests was imperative to confront fascism in Spain. This shift in thinking was particularly difficult for those class-oriented groups which had believed class consciousness took primacy above all else.

Going back to the 1930s, anarchists in Spain were better prepared for intersectional thinking once they encountered fascism because of their broader desire to dismantle all forms of hierarchical domination. Martha Akelsberg argues, 'Where socialists have traced the roots of all domination to the division of labour in the economy, anarchists have insisted that power has its own logic and will not be abolished through attention to economic relations alone.21 Fascism, a hierarchical and homogenising ideology, can only be combated

19 Louie Dean Valencia-García, ed., Far-Right Revisionism and the End of History: Alt/Histories (London: Routledge, 2020), 306.

20 Audre Lorde, Sister Outsider: Essays and Speeches (Berkeley, California: Crossing Press, 2007), 6.

21 Martha A. Ackelsberg, Free Women of Spain: Anarchism and the Struggle for the Emancipation of Women (Oakland, California: AK Press, 2005), 37. 
through a disentanglement of the categories of 'other', acknowledging the different ways in which people have been marginalized from power, whilst simultaneously recognising the differences between those categories of oppression. Only through the ability to empathise and relate one's own pain or plight with those of others - a recognition of the value of both individuality and the collective - can pluralistic struggle emerge. Pluralism, I argue, is the enema to fascism and is at the core of antifascism. In short, to be a proponent of pluralistic ideologies that deconstructed hierarchical power structures in Franco's Spain of the late 1970s-anti-colonialism, anti-racism, feminism, queer liberation and socialism - was to combat the fascistic culture that had festered under Francoism. The only real solution to fascism was the teaching, acceptance and recognition of pluralism which requires the embracing of difference.

By the 1970s, Spanish antifascists were not just anarchists and communists of old, but also hippies and hedonists, university students and intellectuals, children of leftist Spanish Civil War fighters, Basque and Catalan separatists, feminist activists and queer liberation organisers-who drew from influences as broad as contemporary anti-colonialist movements to the British and American punk scenes. Antifascism was not simply a political ideology, but it also was an anti-Francoist practice-which included a desire for broad cultural reforms - to move from an authoritarian monoculture to a pluralistic and democratic society. Although many of these Spaniards were certainly suspicious of Americanisation, many also found the images and rhetoric of American counterculture and the black freedom struggle as particularly helpful and attractive in challenging hegemonic Francoist discourse. In their own way, these antifascists implemented intersectional thinking and practice in their everyday lives that pushed Franco's Spain toward pluralism.

\section{Antifascist Intersections Between Communist, Feminist and Anti- Imperialist Struggles}

Women have long been integral to communist movements in Spain, but, with few exceptions, always isolated from positions of power. Prior to the Spanish Civil War, the most influential women in the Spanish communist movement, Dolores Ibárruri (1895-1989), known as 'La Pasionaría' ['The Passionflower'], was a Basque communist politician who rallied Madrid behind her slogan 'No pasarán' - they shall not pass. Her story remains one of the most powerful examples of antifascist mobilisation during the Spanish Civil War. Whilst women's liberation was certainly a consideration for communists of that period, for the most part it was seen as secondary to a class revolution. For many 
communists, women's oppression was something to be resolved after capitalism was dismantled. This more linear understanding of how oppressions could be unravelled becomes more understandable given the experiences of communist women in the early twentieth century. Ibárruri remembered her life as a young woman in her 1966 memoir, '[W] e were supposed to dedicate ourselves wholly to giving birth, to raising our children, and to serving our husbands who, for the most part, treated us with complete disregard'. She continued, 'In the mine, the woman was a worker and, as such, she could protest exploitation together with other workers. In the home, she was stripped of her social identity; she was committed to sacrifice, to privation, to all manner of service by which her husband's and her children's lives were made more bearable.'.22 Women, like Ibárruri, found autonomy amongst communist parties—but still had a keen awareness that the struggles women faced were different to those of men. For her, the class struggle could give her a place of autonomy if not liberation. However, by the 1970s, Spanish communists were radically reimagining what their struggle looked like.

In the final years of Franco's dictatorship some clandestine Spanish communist groups, such as Frente Revolucionario Antifascista y Patriota [FRAP; Revolutionary Antifascist and Patriotic Front] saw women as necessary to any sort of success they sought. FRAP first began its initial formations in January 1971 in the Paris apartment of Arthur Miller, the Pulitzer prize-winning Jewish-American dramaturge and former husband of Marilyn Monroe. Miller had known communist ties, most prominently made public during his testimony at a 1956 hearing of the United States House Committee on Un-American Activities. Representing the Partido Comunista Española [PCE: Communist Party of Spain] were Raúl Marco, Elena Odena (alias: Benita Fernández) and Lorenzo Peña (alias: E. Zújar). Representatives from the Comités Antiimperialistas (CAI) and the Frente Español de Liberación Nacional de Vanguardia Socialista [Spanish Socialist Vanguard National Liberation Front] were also in attendance. ${ }^{23}$ Paris was certainly a safer location for such a meeting than Spain would have been at the time, giving these representatives a chance to come to some sort of consensus.

Within a year of that meeting, the Committee for the Frente Revolucionario Antifascistay Patriota, by then established as a Madrid-based Marxist-Leninist

22 Dolores Ibárruri Gómez, They Shall Not Pass: The Autobiography of La Pasionaria (New York: International Publishers, 1966), 59-62.

23 Francisco José Setién Martínez, 'El F.R.A.P. Entra en escena (Mayo de 1973): discursos, mensajes y opiniones en la prensa de la época, Historia y Comunicación Social, no. 4 (1999): $361-377$. 
group, was already publishing the third issue of jAccion! de Madrid. The photocopied pamphlet, published in January 1972, called for 'a year of fighting against the fascist dictatorship and Yankee domination'. In this declaration it became clear that an alliance was made between communists and anti-imperialists as both announced their intersecting goals in that simple statement. The pamphlet's authors outlined the type of person they were interested in recruiting, which included: those 'against the fascist dictatorship'; 'against the Yankee invasion'; 'against hunger salaries'; 'against brutal repression'; 'against classist teaching'; 'against discrimination against women'; and 'against the exploitation and oppression of all people'. ${ }^{4}$ The group claimed to be for 'your liberation, the liberation of your class, the liberation of our people, [and] the popular republic'. Such a claim, three years before Franco's death, was certainly one that could have had grave repercussions under the dictatorship. More importantly, the rhetoric of the group demonstrated a particular nuance in considering both the broader implications of colonisation and imperialism - to say nothing of a strong advocacy for women. The communist/anti-imperialist group stretched to consider issues outside of solely those related to class oppression. Because of the group's explicit antifascist proposition, it was only natural that those boundaries had to be expanded to consider more than what might have been the Marxism or communism of old - although Lenin himself had claimed imperialism 'the highest form of capitalism' in $1916 .{ }^{25}$

FRAP's publications avoided the typical censorship process under the dictatorship through the use of photocopying technology-common in counterculture publications of the period. ${ }^{26}$ One contemporary report circulated in least three hundred illegal publications in 1976 alone. ${ }^{27}$ In addition to a firm stance against the fascist dictatorship, the group called for the establishment of a popular republic that would guarantee democratic liberties for the 'pueblo' [people] and rights for national minorities, the confiscation of large latifundios, the liquidation of what remained of Spanish colonialism, amongst other

24 Translations by the author. Frente Revolucionario Antifascista y Patriota, iAccion! de Madrid, no. 3, January 1972, 3 .

25 Vladimir Lenin, Imperialism, the Highest Stage of Capitalism, republished in Lenin's Selected Works (Moscow: Progress Publishers, 1963). The pamphlet was originally published in Petrograd by Zhizn i Znaniye in 1917 .

26 See Louie Dean Valencia-García, 'Tintin in the Movida Madrileña: Gender and Sexuality in the Punk Comic Book Zine Scene, European Comic Art 11, no. 2 (1 September 2018): 12-33, https://doi.org/10.3167/eca.2018.110202.

27 'Los partidos políticos y las organizaciones obreras tienen trescientos periódicos ilegales,' A.B.C. (Madrid), 28 August 1976, 10. 
calls for social services, etc. ${ }^{28}$ The pamphlet indicated similar pro-FRAP committees being formed across Spain, in: Valencia, Catalunya, Basque Country, Galicia, Andalucía, Castilla y Leon and Castilla-La Mancha. The typed, photocopied pamphlet did not give much information about specific actions but did give young antifascists a sense of belonging to a large network of similarly-minded people. Within a year of the first meeting in Paris, FRAP was becoming a nation-wide network of antifascist activists.

In the February 1973 issue of FRONT, a photocopied pamphlet published by FRAP of Catalunya reiterated many of the aforementioned demands set out in the Madrid-based publication-indicating coordination and consensus amongst the antifascist network. The pamphlet was written in both Catalan and Castilian, and explicitly tied Franco's dictatorship to Mussolini and Hitler, and then elaborated upon the influence which the United States had had in Spain since the 1950s - calling Franco a criminal, and Juan Carlos, the expected heir to the Franco state, a puppet. ${ }^{29}$ The use of both Catalan and Castilian is important as it elevated Catalan's prominence, especially given the harsh restrictions against Catalan language publications under Franco. This bilingualism demonstrated a belief in a pluralism that had been outlawed under the dictatorship. The phrase 'yanqui-fascismo' ['Yankee-fascism'] is used to describe the Francoist state throughout the pamphlet. In particular, this anti-US sentiment indicated a sort of understanding that saw fascism, capitalism and Americanism as interconnected. Indeed, given Hitler's own obsession with Henry Ford (and his antisemitism) as well as the collaboration of US companies such as IBM with Nazi Germany, this was hardly a stretch-to say nothing of US presidents since Eisenhower maintaining a strong relationship with Franco, thereby propping up the dictatorship.

In its report to members, the pamphlet demanded readers incorporate women into the fight against fascism. The report reads: 'Each day more women are joining the people's fight. The Committee Pro-FrAP cordially welcomes all democratic and antifascist women of Catalunya. Their fights and participation in our actions are more and more present-having an important role in picketing, manifestations, strikes, etc.' The group goes on to mention work being done to address the exploitation of women who worked in the homes of others-praising the work done by the Unión Popular de Mujeres [Women's Popular Union]. ${ }^{30}$

28 Latifundos were the large estates which primarily belonged to the aristocracy and military elite. During Franco's dictatorship, Spain held colonies in the North African cities Melilla and Ceuta, which it still holds.

29 F.R.A.P. of Catalunya, FRONT, no. 7, February 1973, 2.

30 Ibid., $2-3$. 
Women were prominent in FRAP's militant participation, ${ }^{31}$ and were often listed amongst those arrested and prosecuted in newspapers. In the summer of 1975, more than fourteen members of FRAP were detained for the murder of a police officer. Curiously, and not unimportantly, A.B.C., the Francoist newspaper, cited María Nieves Moral Montero as being responsible for the 'propaganda apparatus' of FRAP. Somewhat salaciously, the newspaper listed her personal details-age, marital status, street address, and named her lover, José Ramón Vizcaíno, on the front page of the newspaper. Indeed, such tactics by the government mouthpiece had the effect of attempting to enforce heteronormativity by bringing shame to Moral Montero's family because of the daughter's indiscretions both with the antifascist group and her relationship. Two other women detained were Milagros Pons Guillén and Raquel López Navarro. ${ }^{32}$ Other antifascist women arrested, detained, or condemned for association with FRAP, included: Teresa de Dionisio y Gómez, ${ }^{33}$ María Jesús Dasca Penelas, Concepción Tristán López, ${ }^{34}$ Francisca Molinos Barrios 'La Gallega', ${ }^{35}$ Beatriz-Gregoria Rodríguez Pérez, ${ }^{36}$ María José Cano Guardiola ${ }^{37}$ and María Milagrosa Navarro Mora. ${ }^{38}$ Whilst dozens of associates of FRAP were arrested during the 1970s, the number of women arrested, even if incomplete, indicates women had roles that put them in very real danger. The fact that so many women did interact with police, and often were given prison sentences, demonstrates clear evidence that FRAP, as a coalition, did see women as part of the fight against fascism.

\section{Amnesty and Equality for Women: A Socialist Youth Argument}

Such appreciation of women and women's issues was not limited to the FRAP, but also was found in later Spanish publications, such as Renovación, the publication of the Federación Nacional de Juventudes Socialistas [National

31 For more on women in FRAP, whose participation Mónica Moreno Seco describes as 'prominent' see: 'Mujeres En el FRAP: Género, militancia y violencia en España durante los años setenta,' Historia Del Presente 33, no. 1 (September 2019): 11-40.

32 'El FRAP, desarticulado por la policía madrileña', A.B.C. (Madrid), 24 July 1975, 53.

33 'Detenidos dos presuntos miembros del FRAP', A.B.C. (Madrid), 4 November 1975, 17.

34 'Tres militantes del FRAP, en libertad,' A.B.C. (Madrid), 17 July 1977, 14.

35 'Es detenido el presunto asesino del policía armado Ruiz Muñoz,' A.B.C. (Andalucía), 17 October 1975, 26.

36 'Amplia operación policial en Valencia y Barcelona,' A.B.C. (Madrid), 21 September 1975, 15.

37 Ibid.

38 Ibid. 
Federation of Socialist Youths]. The magazine focused on class issues, but also considered other social issues more broadly-although some like the author 'W. Reich' tended to exclusively blame capitalism for sexual repression. ${ }^{39}$ In its December 1976 issue, the socialist youth magazine's cover story titled 'Sexuality and discrimination of the Woman' tackled the lack of sex education young girls received. An image from the Asociación Universitaria para el Estudio de los Problemas de la Mujer [AUPEPM; University Assocation for the Study of Women's Problems] accompanying the article asserts: 'Sexuality is not maternity/Rights for our bodies.' ${ }^{40}$ The AUPEPM, led by Isabel Couso, brought together diverse political groups, including, socialists, anarchists and communists. ${ }^{41}$ The article argues many Spanish women believed that a loss of self-worth accompanied the loss of virginity. This loss then somehow justified to women why they had lower salaries; they were literally worth less. Further, the article addresses the fact that women, too, can have orgasms, and more importantly claims sexuality does not have to be tied to reproduction because contraceptives methods can 'permit a woman to freely use her body without running the risk of endangering her body' 42 In this sense, women were able to argue for control over their reproductive labour and safer working conditions. Through this subtle analysis we can see there were ways of thinking about class and gender that were more pluralistic and intersectional.

Another article focused on Spanish marital laws highlighted the case of Angeles Muñíz, a woman in Barcelona who was accused of adultery by her husband-losing rights to her daughter whilst waiting for her court case to be heard. In Madrid, Cecilia G.F. and Aurelio M.R. were condemned to seven months in prison because of an accusation by Cecilia's husband. The article underlines the consequences of the lack of divorce as an option for women. Because of these inequalities, the article continues, some two thousand people, mostly women, protested, demanding 'Equality under the law! Amnesty for women's crimes! Yes, to divorce, no, to adultery! No to women's unemployment! Legalization of contraceptives for women!.43 Clearly, this organisation, which was composed of a broad coalition of socialists, found that sexuality and women's issues were particularly important to address on their own, away from arguments about capitalism or class consciousness—but simultaneously

\footnotetext{
39 'Lucha sexual de los jóvenes,' Renovación, Extraordinary number, undated (c. 1976), 14-15.

40 'Sexualidad y discriminación de la mujer,' Renovación, December 1976, 11.

41 'Se oponen a que el feminism sea bandera política,' El País, 3 December 1976, Sociedad section.

42 Renovación, December 1976, 11.

43 Ibid.
} 
important for all those interested in socialism. Indeed, sexuality as a topic for young people perennially is important, but more so when sex acts can have grave repercussions under a late fascist regime which imposed very clear traditionalist expectations for women. By dedicating consistent attention to women's issues, and to the ways in which to participate in feminist actions, the socialist magazine included those issues as part of its call for a proletariat revolution - a slogan that was found prominently in the front cover of the magazine. In this way, feminism and socialism became interdependent issues.

In 1973, the Spanish Tribunal Supremo estimated some 300,000 illegal abortions reported per year in Spain, according to Spain's Grupo Feminista de Planificación Familiar [Feminist Group for Family Planning]. ${ }^{44}$ In its March 1977 issue of Renovación, along with a call for numerous leftist groups to demand the right for eighteen-year olds to vote ${ }^{45}$ the magazine featured a twopage spread titled 'An Illegal Reality: Abortion', ${ }^{46}$ The article described a lack of sexual education for Spanish women and 'social discrimination against single mothers'. The article explains, 'Abortion in this country is created by the null in sexual education that we young people receive, until now the topic of sexuality in all Spanish families has been a Christian moral taboo. ${ }^{47}$ Interviewing a doctor in Amsterdam who provided abortions, the doctor explained the risks and puts to rest the popular beliefs that having an abortion can produce sterility, sexual diseases or negatively affect future children. The article goes on to give the addresses of doctors providing abortions in Paris, Amsterdam, London and Bayonne. An accompanying cartoon depicted a woman telling her partner that she is pregnant, his response: 'What joy! And when do we announce the wedding? The woman responds: 'I do not want to maaarried! I want to be a freeee woman'. The man responds in shock, 'iNo!' The article ends, 'We must transform reality and ... all young people must mobilise themselves and demand, just like any other right, the abolition of articles 411 and 417 of the Penal Code and, furthermore, the legalization of abortion, making social security cover those costs. 48 These legal demands represented not just an understanding of relevant social issues, but also the ways in which the Franco regime had codified the oppression of women.

44 'Grupo Feminista de Planificación Familiar,' Cuadernos para el Diálogo, July 1978, 3 o.

45 Some of these groups specifically listed in this call included: the Union of Young Communists, the Youth Red Guard, the Communist Youth Movement, the Leftists Democratic Youths, the Maoist Youths Union and their own Young Socialists group.

46 'Una realidad legal: El aborto,' Renovación, March 1977, 10-11.

47 Ibid.

48 Ibid. 
Below the extensive spread on abortion, Renovación published an article demanding amnesty for the end of repression of Basque Country—which had its language and culture brutally oppressed under the dictatorship..$^{49}$ The magazine also featured a story on youth unemployment and a call to boycott the Spanish department store El Corte Inglés because of its refusal to renegotiate the return of former workers-primarily young women. An article proposing Civil Service in lieu of military service was featured, as was one reporting the legalization of Juventudes Socialistas - demanding the legalization for all political organisations. The variety of stories demonstrated a clear strategy to show some of the ways different youth groups' interests intersected, as well as those of Basque citizens and women. Significantly, the desire for civil service over military service indicated a desire to de-militarise the country. Taken together, these stances were antifascist. They might not have used the language of intersectionality, but such thinking was certainly present in the issues Renovación chose to highlight.

Whilst much of the coverage of these social issues might seem coincidently antifascist, one page-long article, 'The International Crime', specifically takes on fascism: 'Lately there has been much talk of the existence of a Fascist International. We are facing a mechanism, a plot, which receives economic, moral and political support from ideological organisations, police services and intelligence services. It is the same face of fascism that does not resign itself to disappearing and is reorganised internationally'. The article continues, 'the plan of action by international fascism is focused on countries-like Spainthey have a strategic position, intervening in the form of what has been called political and economic destabilization and also making use of infiltrations or creation of supposedly left-wing organisations. ${ }^{50}$ The article essentially asks readers to watch out for fascist infiltration of leftist communities. Whilst the article reads somewhat like a fascist conspiracy theory, it demonstrates both a very real antifascist message and a preoccupation about potential common enemies found in the pamphlet and amongst readers.

\section{Anarchists and the Destruction of Hierarchies}

Anarchism evolved out of democratic and pluralist ideas of the Enlightenment - a form of 'anti-monarchism' — which promoted democratic and pluralistic ideologies. Nineteenth century anarchism came to incorporate

49 Ibid, 11.

$50 \quad$ 'La internacional del crimen,' Renovación, March 1977, 14. 
contemporary ideas of socialism, but many anarchist thinkers took issue with Karl Marx's belief in the need of a 'dictatorship of the proletariat' - believing in an ultimate goal of deconstructing oppressive hierarchies. In anarchism's confrontation with fascism, particularly in the Spanish Civil War and over the long twentieth century, Spanish anarchism evolved to consider not just issues of class, race, ethnicity, gender and sexuality, but also fought colonialism, environmental dangers and the carceral state. Spanish anarchists' marginalisation by fascism and their severe oppression under Franco, had sharpened their acuity and understanding of hierarchical oppression beyond just socio-economic class (though class consciousness remained a clear and important goal). ${ }^{51}$ To this point, liberation feminism existed even in Spanish anarchism of the early twentieth century. ${ }^{52}$ This, too, spread to other leftist groups and parties.

Anarchism as an ideology, found its way to antifascism because its fundamental tenets opposed any sort of hierarchal society and celebrated the value of individual autonomy in its confrontation with fascism - an opposition most clearly in evidence during the Spanish Civil War. Anarchism values local community and inclusion through a consensus building process. If fascism is centralising and homogenising, anarchism is decentralising and pluralist. In fact, I argue anarchism became 'intersectional' in response to fascism's own tendencies. In order to dismantle fascist hierarchies, there was only one potential ideological recourse-pluralism. In a sense, fascism demonstrates intersectional jingoism, which required anarchism to also be intersectional in order to fight for its goals of individual autonomy, pluralism and a non-hierarchical society.

Although there were attempts to build antifascist coalitions in Spain in the 196os, particularly by the anarcho-syndicalist Confederación Nacional del Trabajo [CNT; National Confederation of Labour], organising a nation-wide anarchist movement proved impossible until the end of Franco's life. ${ }^{53}$ The CNT and the Federación Anarquista Ibérica [FAI; Iberian Anarchist Federation] were two of the most significant organising anarcho-syndicates prior to the Civil War. In 1977, an Amnesty Law was passed pardoning both leftist political figures and those who had actually participated in the Francoist regime's human rights abuses. ${ }^{54}$ This had the double effect of creating a clean slate in which both the far right and the left could coexist, but also resulted in a sort

\footnotetext{
51 Gonzalo Wilhelmi, El movimiento libertario en la Transición: Madrid 1975-1982 (Madrid: Fundación Salvador Seguí, 2012), 45.

$5^{2} \quad$ For more see: Ackelsberg, Free Women of Spain.

53 Javier Muñoz Soro, 'In Search of the Lost Narrative: Antifascism and Democracy in PresentDay Spain,' in Rethinking Antifascism: History, Memory and Politics, 1922 to the Present, ed. Hugo García et al. (New York: Berghahn Books, 2016), 279.

Boletín Oficial del Estado, no. 248, 17 October 1977, 22765-22766.
} 
of historical amnesia of the Spanish Civil War as centrists preferred to simply ignore the history of fascism in Spain..$^{55}$ With the passing of the Amnesty Law, anarchism returned to the political stage, but never reclaimed the position it had prior to the Spanish Civil War-though, arguably, its ideologies heavily influenced the later 15 of May Movement $(15-\mathrm{M})$ which spread across Spain in Spring 2011, as well as the Occupy Wall Street movement in the United States that summer. Many of the ideas that became prominent in the second decade of the twenty-first century began in anarchist circles of the 1970s, particularly in Spain.

One anarchist magazine, Bicicleta [Bicycle], took the lead in this effort to update anarchism for a new era. On the cover of first issue of Bicicleta (1978), a Native American figure is shown smiling, riding a bicycle through a grassy field. He is happy, care free and holds a tomahawk in his extended arm. The image of the joyous, muscular Native American holding a weapon, riding a bicycle, is not quite explained. To be sure, the image hardly seems to make sense other than to dispel the images of the 'uncivilised savage' propagated by American cowboy films, that often featured the likes of John Wayne, popular in Spain during the mid-twentieth century. The first issue included mostly articles related to worker's rights, upcoming Spanish elections, international worker's consciousness, nuclear energy and discussions of the intersections of ecology and revolution. Whilst the magazine clearly attempted to move discussion away from issues solely related to workers, incorporating ecological issues, it still had not made the leap toward becoming explicitly antifascist until its second issue.

The second issue of Bicicleta included a 'Manifesto against Social Marginalisation', which called for the abolition of the laws that categorised people as vagrants, ruffians, psychopaths or those with a predisposition to crime. It demanded the abolition of so-called 'rehabilitation centres' for homosexual people, the right for free use of one's own body as they wished, the end to all legislature discriminatory toward women, free education and the right to work. This manifesto also included an end to discrimination against Roma communities [gitanos], North Africans [moros] and immigrants. ${ }^{56}$ With this manifesto, the anarchist magazine seemingly took to heart that all of these issues were interconnected and necessary to confront simultaneously.

Demonstrating a larger consensus for a need for what we might describe as intersectional thinking, the third issue of Bicicleta featured an article

55 See: Paloma Aguilar Fernández, Memory and Amnesia: The Role of the Spanish Civil War in the Transition to Democracy (New York: Berghahn Books, 2002).

$5^{6}$ 'Los grupos marginados se presentan,' Bicicleta, no. 2, December 1978, 38-39. 
which reported on recent anarchist assemblies held in Barcelona which had demanded two things:

1. An analysis of the State and capitalist system; an analysis of our objective, libertarian communism; the elaboration of a coherent program of action that creates the basis for a strategy as well as adequate tactics to do so, parting from the current situation, toward libertarian communism.

2. Taking into consideration different social movements (worker and unionist movements, nationalities, marginalised people, ecology, feminism, naturalism, countercultural movements, and neighbourhood stuggles, etc.), there is a need to analyse the current situation in these areas: analysing the objective that we all propose to achieve in each of those movements whilst determining how this analysis can serve as instruments to achieve our objectives. ${ }^{57}$

In no uncertain terms, the magazine proposed both intersectional analysis and antifascist action-recognising that there were overlapping interests.

The anarchist magazine deliberately attempted to place itself into a European context, featuring news from the United Kingdom, France, Greece, Sweden, Germany and the Netherlands. The news from the UK discussed a group of immigrant workers at the Grunwick film processing laboratories who were in the midst of a year-long strike. The workers, primarily South Asian immigrant women, had endured 'abandonment by official unions' and 'attacks from the police, fascist bands, the press' 58 The strike lasted nearly two years and received wide press coverage in the UK from 1976-1978, and 'was the first time that a woman of colour [Jayaben Desai] engaged in strike action and occupied the front page of the British press'.59 One flyer distributed in the UK around the same time described the Grunwick strike as about 'immigrants', 'women', 'trades union rights', and 'working class solidarity'. The flyer read: 'The Grunwick Strike started a year ago about sweat shop working conditions, unscrupulous exploitation of people least experienced and least organised to defend themselves: women and immigrants. It is about low wage rates and harsh management'.60 Whilst the strike never won

57 'Las asambleas de Barcelona,' Bicicleta, no. 3, January 1977, 20.

58 'Banda ultraderechistas incitan a la policía a la represión,' Bicicleta, no. 1, November 1977, 28-29.

59 For more on the strike itself see: Linda McDowell, Sundari Anitha and Ruth Pearson, 'Striking Narratives: Class, Gender and Ethnicity in the 'Great Grunwick Strike', London, UK, 1976-1978,' Women's History Review 23, no. 4 (2014): 595-619.

6o Flyer featured in: Evan Smith, 'The intersection of race, class and gender at the Grunwick Strike,' Hatful of History, 23 August 2015, https://web.archive. 
support from the powerful British Trades Union Congress, the strike did endure for two years and 'inspired antifascist solidarity as well as actions such as the lesbian and gay support for the miners in the 1980s. ${ }^{6} 62$

Jayaben Desai had migrated from India by way of Tanzania, and was the leader of the Grunwick Strike and was even photographed holding a sign that read 'The workers united will never be defeated'-a riff on the 1973 song 'El pueblo unido jamás será vencido' by Sergio Ortega and Chilean the folk music group Quilapayún. ${ }^{63}$ Indeed, whilst Spain did not have as much of an immigrant population as other western European countries of the period, primarily because of the dictatorship's policies and the earlier loss of the Spanish colonies, there was certainly recognition of the ways race played into worker's issues by the anarchists who produced Bicicleta, demonstrating a shift toward pluralistic and intersectional understanding of social issues.

\section{Intersectionality in 1970s Spanish Countercultures}

Although what we might call the closest thing to intersectional approaches was most prominently found in anarchist circles, such intersectional thinking was also found in popular culture as well. Throughout the 1970s, a countercultural scene had blossomed, reaching its full potential in the early 1980s-in which many of the most marginalised groups under the dictatorship took centre stage. Olvido Gara Jova, one of the main protagonists of this scene, sometimes known as 'El Rrollo', Spanish New Wave, or 'La Movida madrileña', early on had developed both an appreciation of feminism and queer issues. In the first issue of Liviandad del Imperdible [The Lightness of a Safety Pin], a countercultural fanzine dedicated to comics, punk, and anarchism, dated October 1977, the then fourteen-year old Gara Jova, later known as the New Wave musician artist 'Alaska', published an essay titled 'Libertad para la mujer española: Yaaaa?' [Liberty for the Spanish Woman: Nowwww? ?. The article argued 'Nietzsche's superman is a woman' and also that 'women are superior to men, because they

org/web/2018052818325o/https://hatfulofhistory.wordpress.com/2015/o8/23/ the-intersection-of-race-class-and-gender-at-the-grunwick-strike/.

61 Navendu Mishra and Marcus Barnett, 'We Are The Lions, Mr. Manager,' Jacobin Magazine, 20 August 2017, https://web.archive.org/web/20170824125932/https://jacobinmag.com/2017/o8/ we-are-the-lions-mr-manager.

62 Paul Lewis, 'Jayaben Desai, leader of the Grunwick dispute, dies aged 77, The Guardian, 27 December 2010, https://www.theguardian.com/politics/2010/dec/27/ jayaben-desai-dies-aged-77.

63 Ibid. 
are less animalistic' ${ }^{64}$ More transgressively, the article also defended a women's right to bisexuality, and lauded feminism. ${ }^{65}$ Alaska's prominence in this discourse was particularly important given she grew up in Mexico, the child of a Cuban mother and a Spanish father. In many ways, she was herself a representation of intersectionality in practice by making space for herself-eventually becoming one of Spain's most famous musicians, as well as a television host and actor.

This intersectional thinking was also seen in the writings of Spanish poet and writer Eduardo Haro Ibars. Haro Ibars, who grew up partially in Morocco and France, wrote and promoted both the use of drugs, delinquency and homosexuality in his life and writing. He read broadly and was keenly interested in social movements abroad. In 1975, prominent Spanish cultural critic Jesús Ordovás positively reviewed Haro Ibars's new book, Gay Rock, in the pages of the cultural-political magazine Triunfo. Ordovás called Gay Rock (and arguably Haro Ibars's way of life) 'aggressive', 'anarchist' and 'fresh'.66 Haro Ibars was open about being both gay and libertine-minded. In his article 'The road to liberty of the body', Haro Ibars describes laws which punished homosexuality, sex work, and drug addiction. Despite primarily focusing on queer issues, the article expands to consider ways in which bodies are oppressed, particularly those engaging in sex work. The article includes a photograph of a woman holding a sign claiming 'I am Lesbian and I am Beautiful' - which Haro Ibars connects to the 'Black is Beautiful' slogan prominent in the United States at the time. This article clearly brings together issues of queerness, race and gender together, along with those of incarceration, in a way that was clearly intersectional and pluralistic. ${ }^{67}$ Although the concept of intersectionality would not come to be defined until much later, such thinking certainly was a necessary form of analysis in Spain in the 1970s and Spaniards looked both internally and abroad for ways to name overlapping interests and to name and disentangle fascistic systems of power.

In another article in Triunfo, 'Documents against Normalidad', Haro Ibars describes how groups with seemingly disparate interests started to find their ways toward each other:

First it was the racial minorities, mostly in the United States, where the situation for Blacks, Chicanos, and other ethnic groups was and is intol-

64 Olvido Gara Jova, 'Libertad para la mujer española: Yaaaa?' La liviandad del imperdible, October 1977, 12.

65 Ibid.

66 Jesús Ordovás, “El "gay rock”, entre la decadencia y la revolución,' Triunfo, 21 June 1975, 6o.

67 Eduardo Haro Ibars, 'El camino hacia la libertad del cuerpo,' Triunfo, 26 February, 42-43. 
erable; this fight then later added women, who made public their discontent with the social system and sexist culture... and, later, other groups joined: groups that had rarely spoken a word: for example, homosexual liberation groups, or those with psychiatric issues, or drug users, or radical ecological groups. ${ }^{68}$

Bringing the issue to Spain, Haro Ibars cites that at first these groups seemed to have nothing in common, often being left out of traditional leftist groups, but soon found that they were able to find 'compañeros de viaje', or travelling companions. ${ }^{69}$ These travelling companions, in effect, were people with intersecting interests.

\section{Antifascism is Pluralistic Practise}

Today, if one passes the Madrid offices of the Union General de Trabajadores [UGT; General Union of Workers], a trade union historically associated with the Partido Socialista Obrero Español [PSOE; Spanish Socialist Worker's Party] one sees a rainbow coloured flag with the UGT's logo displayed in addition to the traditional red version of the flag. This awareness of queer issues by socialists, and other leftist groups, began in earnest at the twilight of Franco's Spain, when such groups realised that it was necessary to first think intersectionally in order to unravel the fascistic culture and structures that existed in Spain until the 197os through pluralism and coalition building.

By looking at ways in which intersectional analysis became articulated in a country that was transitioning out of a late fascist dictatorship we can better understand how that analysis led to antifascist pluralism. By pushing for reform both at the policy level and at the cultural level, these antifascists had identified ways in which a sort fascism had permeated everyday life - something that was hardly unique to Spain as seen in their solidarity with their compatriots abroad. Moreover, these cases demonstrate why intersectional analysis is necessary to understand how to name and deconstruct fascistic practises. Through intersectional analysis an antifascist practice can develop-one that is pluralistic in its nature because of an understanding of the ways in which fascist tendencies attempt to categorise and marginalise people within a hegemonic hierarchy. Antifascism can take many forms, but before arriving to those strategies and tactics, a clear understanding of fascistic categories must

68 Eduardo Haro Ibars, 'Documentos contra la normalidad,' Triunfo, 8 December 1979, 58-59.

69 Ibid. 


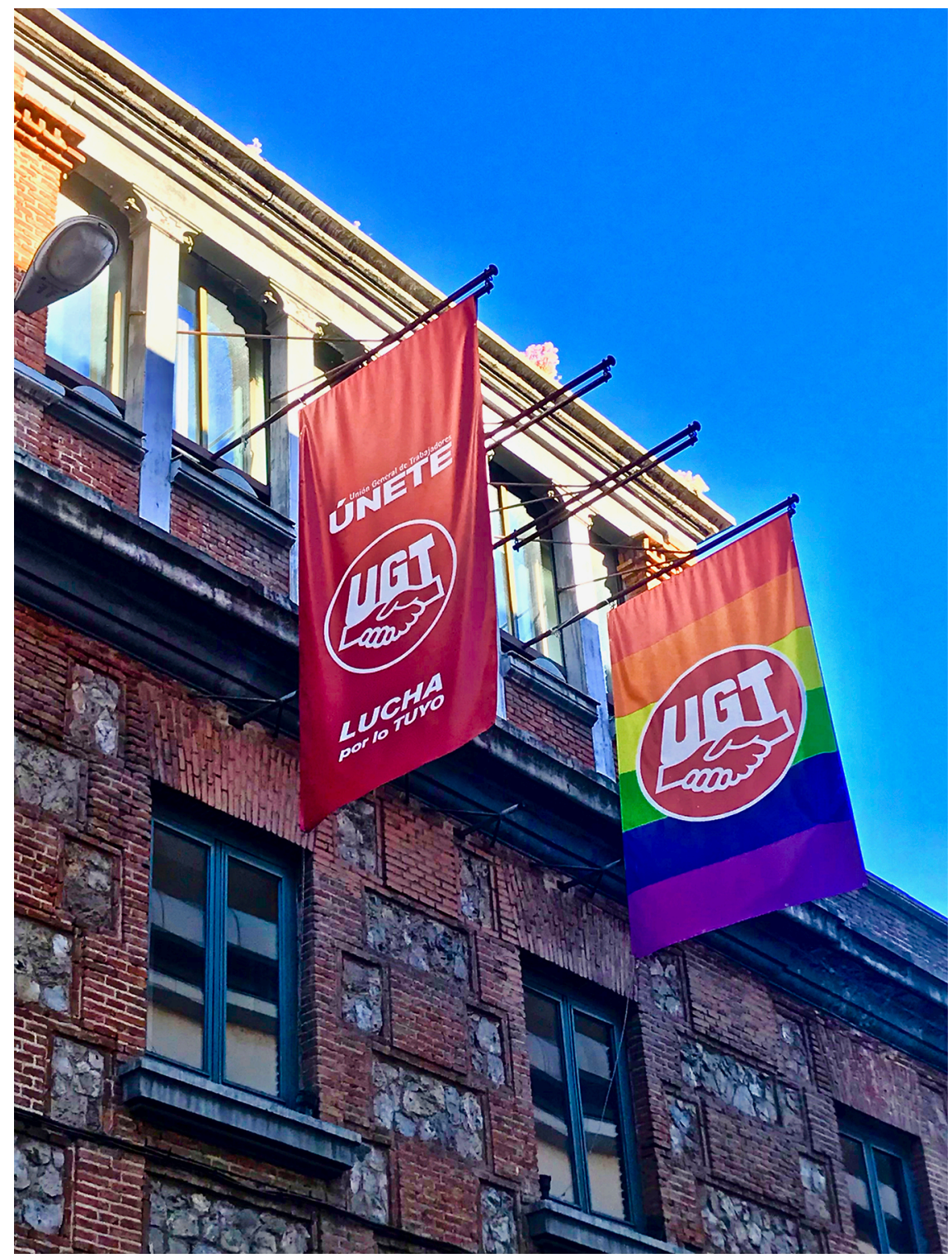

ILLUSTRATION 1 The General Union of Workers' offices in Madrid featuring rainbow flag. Photo: Louie Dean Valencia-García.

be understood. Whilst impossible to define antifascism, it must be understood not as simply standing against fascism, but as understanding those with whom one stands and must include a pluralistic practise- -bringing together diverse peoples, interests and cultures-, something fascism itself cannot do. 